\author{
Stanisław Dubisz \\ Uniwersytet Warszawski \\ Instytut Polonistyki Stosowanej \\ Zakład Komunikacji Językowej i Glottodydaktyki
}

\title{
KATEGORIA POKOLENIA W DIALEKTOLOGII
}

Słowniki ukazujące zasób leksykalny polszczyzny w okresie jej najnowszych dziejów - tj. po 1939/1945 roku - [Dubisz, 2006, s. 134-140] uwzględniają następujące znaczenia leksemu pokolenie:

1. 'potomstwo tych samych rodziców', biol. przemiana pokoleń; 2. 'ród, plemię, dynastia, linia': pokolenie Dinka [chodzi tu o plemię afrykańskie - S.D.], Lecha pokolenie, pokolenie jagiellońskie; 3. 'ogół ludzi urodzonych i żyjących w tej samej epoce': nowe pokolenie artystów, „objąłem w ramiona wszystkie przeszłe i przyszłe pokolenia” (A. Mickiewicz, Dziady) [zob. Doroszewski, red., 1964, t. V, s. 835-836].

1. 'grupa ludzi (także zwierząt lub roślin) będących mniej więcej w tym samym wieku; generacja': pokolenie dwudziestolatków, biol. przemiana pokoleń, fraz. starsze pokolenie; 2. 'ogół ludzi ukształtowanych przez podobne lub te same przeżycia, doświadczenia itp.': pokolenie wojenne, pokolenie JP II, lit. pokolenie Kolumbów, fraz. inteligent, lekarz, prawnik w pierwszym, drugim... pokoleniu; 3. 'okres równy długości życia ludzi urodzonych w podobnym czasie': dwa pokolenia wstecz; 4. 'członkowie jakiejś rodziny, będący w podobnym wieku i zajmujący w niej taką samą pozycję': cztery pokolenia naszej rodziny - pradziadkowie, dziadkowie, rodzice i my - dzieci [zob. Dubisz, red. nauk., 2003, t. VI, s. 614].

Na podstawie powyższych notacji słownikowych łatwo możemy zauważyć, że w ciagu półwiecza zaznaczyła się tendencja do specjalizacji znaczeń tego leksemu, chociaż - jak w całych jego dziejach - na plan pierwszy wysuwa się tu generacyjno-społeczny składnik znaczeniowy, mający zresztą uwarunkowania etymologiczne:

Psł. * pokolénbje 'ogół potomstwa rodu, plemienia', od wyrażenia przyimkowego * po kolěnu od psł. * koléno, które oprócz znaczenia anatomicznego 'kolano' miało też znaczenie 'pokolenie, ród, plemię' (por. cz. koleno 'pokolenie, generacja', r. koléno 'pokolenie, plemię, 
ród', ch./s. koljeno 'ts.'; zob. kolano), co do tych znaczeń por. też łac. genū (genus) 'kolano' i genus 'ród, rodzaj, grupa, pochodzenie; potomek, potomstwo; szczep, plemię, lud, naród' [Boryś, 2005, s. 457].

Dodać tu trzeba również, że już psł. rzeczownik * kolěno (< pie. * kuel- 'obracać, kręcić') pierwotnie oznaczał 'zakrzywienie, zagięcie, zginającą się część ciała', ale także 'roczną odrośl u roślin' oraz (w wyniku metaforyzacji) 'generację, ród' [zob. Sławski, 1958-1965, t. II, s. 342-343].

Wyodrębnienie się dwóch podstawowych aspektów znaczenia leksemu pokolenie, wyraźnie zaznaczonych we współczesnych definicjach tego rzeczownika, widoczne jest w staropolszczyźnie. Stownik staropolski wyróżnia tu dwie parafrazy znaczeniowe: 1. 'potomstwo pochodzące od jednego przodka', 2. 'ogół ludzi urodzonych i żyjących w tej samej epoce' [zob. Urbańczyk, red., 1972 , t. VI, z. 5, s. 320]. W tym wypadku mamy do czynienia z wydzielonym zakresem biologicznym (generacyjno-społecznym) i chronologicznym (generacyjno-kulturowym). Łatwo można zauważyć, że generacyjno-kulturowy zakres znaczeniowy jest wtórny wobec zakresu generacyjno-społecznego.

Nauki społeczne wyróżniają tu dwa rozumienia pojęcia ,pokolenie”- biologiczne ( w naszym ujęciu = generacyjno-społeczne) i społeczno-kulturowe ( w naszym ujęciu = generacyjno-kulturowe). $\mathrm{W}$ pierwszym rozumieniu, oprócz określenia pokolenia biologiczne, bywa stosowana nazwa pokolenia rodzinne, w drugim oprócz określenia pokolenia społeczno-kulturowe, bywają używane nazwy pokolenia społeczne, polityczne, ekonomiczne, kulturowe [zob. Kamińska, 2007].

$\mathrm{Z}$ ujęciem generacyjno-społecznym (biologicznym, rodzinnym) łączy się ustalenie chronologicznej ciagłości czyli długości trwania pokolenia. Poczynając od Herodota (V w. p.n.e.), który podawał, że trzy pokolenia wynoszą 100 lat, i Mateusza Ewangelisty (I w. n.e), który za pomocą liczby pokoleń określał czas od Abrahama do Chrystusa, przyjmowano, że okres trwania pokolenia to od 30 do 33 lat (stąd i ,wiek Chrystusowy”), jednakże różne epoki, a w szczególności dyscypliny naukowe, w sposób zróżnicowany modyfikują tę chronologizację.

Ujęcie generacyjno-kulturowe wymaga określenia wspólnych przeżyć generacyjnych na tyle silnych, że wyzwalających poczucie wspólnoty i wyodrębniających tych, którzy ich doświadczyli, od poprzedników i następców (Kolumbowie rocznik 20., pokolenie marca 68, pokolenie JP II). Bywa jednak i tak, że różnica pokoleniowa sprowadza się tylko (czy też aż) do odczucia konfliktu generacyjnego - por. model konfliktu pokoleniowego między "starymi” a „młodymi” w literaturze i sztuce bądź między „starą” a „młodą/nową” emigracją 
w zbiorowościach polonijnych, czy też między „starą” a „nową” inteligencją w 2. połowie XX wieku) [zob. Wyka, 1977; Sękowska 1995; Kurkowska, red., 1981]. Współcześnie daje się zauważyć zanikanie nawet tak rozumianej więzi pokoleniowej:

Współczesnym pokoleniom nie potrzeba wstrząsu w postaci traumy oraz własnej ideologii. Ich program kształtuje nieustannie zmieniający się model społeczeństwa konsumpcyjnego i zagrożenie wyjściem poza poprawność społeczną [Kamińska, 2007, s. 7].

W badaniach lingwistycznych kategoria pokolenia pojawiła się wraz z paradygmatem młodogramatycznym, który język traktował jako indywidualny twór bio-psycho-fizyczny, podlegający przemianom w czasie, ewoluujący jak żywy organizm i dostępny badaniu jedynie w swych stadiach historycznych. W tych ujęciach - podobnie jak w szeregu innych teorii-podstawowymi kategoriami są: następstwo zdarzeń (dziejów) w czasie i następstwo zdarzeń (zmian) w języku. Ewolucja systemu językowego (języka) jest zatem ciągiem zmian, mających swoją istotę, warunki determinujące ich zachodzenie, chronologię i konsekwencje dla samego języka. W procesie historycznojęzykowym należy zatem wyróżnić aspekt wewnętrznojęzykowy (istota zmian $\mathrm{i}$ ich konsekwencje dla systemu) oraz zewnętrznojęzykowy (determinanty zmian i ich chronologia), które pozostają w relacjach rekursywnych [por. Dubisz, 2009, s. 19-20].

Tradycje polskiej dialektologii jako samodzielnej dyscypliny językoznawczej sięgają 2. połowy XIX wieku. Z tymi tradycjami wiąże się określenie przedmiotu badań dialektologicznych, definiowanego jako geograficzne zróżnicowanie języka polskiego, co w praktyce sprowadza się do naukowego opisu systemów polskich dialektów i gwar ludowych, określanych kiedyś szerzej jako mowa ludności wiejskiej [por. Doroszewski, 1953; Nitsch, 1957, s. 7-9; Pelcowa, 2012; Karaś, 2012]. Funkcjonowanie dialektologii w obrębie szeroko pojmowanego językoznawstwa spowodowało wykształcenie się jej dwóch podstawowych kierunków metodologicznych, zgodnych z podziałami zachodzącymi w obrębie językoznawstwa, tj. dialektologii historycznej (diachronicznej) i dialektologii opisowej (synchronicznej). Oczywiście, poszczególni badacze niejednokrotnie w sposób zindywidualizowany ujmowali te dwa działy dialektologii - można tu przykładowo wymienić opracowania Alfreda Zaręby [1955], Witolda Taszyckiego [1961], Witolda Doroszewskiego [1962], Mieczysława Karasia [1968], Karola Dejny [1973, s. 11-15], Władysława Lubasia [1976] . 
W ciagu swego istnienia dialektologia przeżywała różne koleje losu. W wieku XIX powstanie i rozwój dialektologii wiązały się z zainteresowaniami ludowością w okresie romantyzmu, z polityczno-socjalnym programem ,pracy u podstaw" w okresie pozytywizmu oraz z młodopolską ludomanią. Dialektologia rozwijała się wówczas w ścisłym związku z badaniami etnograficznymi i folklorystycznymi. Dominujący wtedy w językoznawstwie polskim kierunek historyczno-porównawczy spowodował jej diachroniczno-retrospektywne nachylenie. Dlatego też do dziś podkreśla się przydatność badań z zakresu dialektologii dla etnografii, folklorystyki, antropologii, historii języka, historii literatury i historii w ogóle [por. Dubisz, 2013, s. 51-52].

Rozwijające się na przełomie XIX i XX wieku oraz w dwudziestoleciu międzywojennym badania z zakresu dialektologii

[...] związane były ściśle ze stanem historycznym, zmierzały do ukazania ewolucji językowych cech pierwotnych, a ostatecznym wynikiem prac miało być wykreślenie izoglos, pokazujących granice poszczególnych cech oraz dialektów w nawiązaniu do prehistorycznych nawet podziałów plemiennych. Starano się w badaniach dotrzeć do ludzi najstarszych, reprezentujących czysty, autentyczny stan gwary, odrzucano formy będące wynikiem bezpośredniego nacisku języka ogólnego [Bajerowa, 2002, s. 11].

Zastosowano zatem w tego typu badaniach kategorię pokolenia w ujęciu generacyjno-społecznym (biologicznym, rodzinnym).

Przy takim założeniu metodologicznym w sposób naturalny informatorzy / respondenci układali się w trzy grupy pokoleniowe: 1) pokolenie młode (najmłodsze) - do 30 roku życia, 2) pokolenie średnie - 30-60 lat, 3) pokolenie najstarsze (starsze) - po 60 roku życia. Tej metodologii hołdowała przede wszystkim krakowska szkoła dialektologii, z jej twórcą Kazimierzem Nitschem, oraz kontynuatorzy tej szkoły, którzy stanowią jedną z orientacji współczesnej dialektologii polskiej. Potwierdzenie tych zasad znajdujemy w publikacjach dialektologicznych. Przykładowo w zbiorze Pótnocno-polskie teksty gwarowe od Kaszub po Mazury pod redakcją K. Nitscha [1955] tylko troje informatorów (na bez mała 30) reprezentuje pokolenie średnie, podczas gdy pozostali należą do pokolenia najstarszego.

Kategoria pokolenia na stałe zadomowiła się w badaniach dialektologicznych niezależnie od orientacji metodologicznej. Twórca warszawskiej szkoły dialektologicznej Witold Doroszewski uważał, ,[...] że celem pracy dialektologa jest uchwycenie prawdziwego, żywego stanu rzeczy, nieraz stanu wykazującego wymieszanie form starych i nowych [...] pokazanie rzeczywistej aktualności, przy tym ujętej ściśle statystycznie” [Bajerowa, 2002]. Owa „rzeczywista aktualność" gwarowa to mowa kilku pokoleń. Dlatego też u badaczy reprezentujących tę 
statystyczno-socjologiczną orientację w badaniach dialektologicznych wykazy informatorów obejmują osoby prezentujące różne pokolenia, choć nie zawsze z uwzględnieniem przedziałów pokoleniowych, co jest uzależnione od celu badań. Anna Basara w swej monografii fonetycznej tak tę sprawę przedstawia:

Przy zbieraniu materiału posługiwałam się przede wszystkim kwestionariuszem fonetycznym [por. Basara et al., 1959 - przyp. S.D.] wypełnianym zasadniczo u jednej osoby, będącej przedstawicielem starszego lub najstarszego pokolenia badanej wsi (osoby w wieku od 60-90 lat).

W niektórych wsiach, np. Zakrocz, Dąbrowa, wypełniałam kwestionariusz dwukrotnie (również i u przedstawicieli młodego pokolenia, tzn. u osób w wieku 20-30 lat). W czasie przeprowadzania badań starałam się zapisywać teksty ciągłe, a także rozmawiać z innymi ludźmi z danej wsi. W pięciu wsiach zrobiłam nagrania magnetofonowe. Większość zamieszczonych w pracy tekstów była najpierw nagrana na magnetofon a dopiero później odsłuchana i przetranskrybowana.

Zdaję sobie sprawę z tego, że nie wszędzie jednak udało mi się zapisać „czystą” gwarę [tj. gwarę ludową bez wpływu polszczyzny ogólnej - przyp. S.D.]. Wpływy języka ogólnopolskiego, powszechne u pokolenia młodego, nierzadko i u osób kilkudziesięcioletnich, były tak silne, że można tam było właściwie mówić o reliktach gwarowych, a nie o gwarze. Mimo przyjętej zasady, że kwestionariusz fonetyczny wypełniony jest u osoby pochodzącej z danej wsi i typowej (reprezentatywnej) dla danej wsi, częstokroć profil wykreślony na mapie lub dokonany zapis reprezentują jedynie mowę typową tylko dla paru najstarszych osób we wsi, w której reszta mieszkańców mówi językiem ogólnopolskim z nielicznymi naleciałościami gwarowymi.

Zastosowanie takiej metody było jednak konieczne, gdyż w przeciwnym razie z góry należałoby zrezygnować, i to na zawsze, z uchwycenia wielu ciekawych i charakterystycznych zjawisk językowych, czasem zachowanych jeszcze u osób starszych, nie występujących natomiast zupełnie u młodszego, a nawet średniego pokolenia [Basara, 1965, s. 9-10].

Mamy w tym wypadku do czynienia z próbą zarejestrowania najstarszej postaci wokalizmu gwarowego z pełną świadomością badaczki co do pokoleniowego zróżnicowania gwary ludowej.

Wielopokoleniowość informatorów w badaniach dialektologicznych staje się niemal obligatoryjna im bliżej dnia dzisiejszego, co wiąże się z intensywnymi przemianami języka wsi, których nie można uchwycić bez uwzględnienia pełnego zróżnicowania opisywanych społeczności wiejskich:

Świadomość historycznej zmienności języka wyraża się stopniem znajomości przez mówiących form językowych „starych” i „nowych”, charakterystycznych dla poszczególnych grup pokoleniowych: dziadków, rodziców. Reprezentanci badanych generacji mają świadomość podwójności słownictwa: czynnego, którym się posługują, i biernego, które rozumieją i o którym mogą mówić, a nawet je objaśniać. Podawane przykłady wskazują na zmiany w słownictwie mieszkańców wsi w kontekście przemian społeczno-kulturowych, na różnice w mowie pokoleń w zakresie leksyki i na przemiany etykiety językowej, będące odbiciem zmian normy kulturowej (obyczajowej). [...] 
Przejawem świadomości językowej mieszkańców Lasocina jest także korekcja w toku mówienia. Dostrzeganie odrębności języka wiejskiego wiąże się przede wszystkim z czynnikami zewnętrznymi, a mianowicie odrębnościami socjologicznymi, a więc: zawodem rolnika, zamieszkaniem na wsi, brakiem wykształcenia. Zróżnicowanie gwary ma swe źródło w różnicach pokoleniowych [Cygan, 2011, s. 13].

Statystyczno-socjologiczna metoda opisu dialektów ludowych i ich przemian, wprowadzona przez W. Doroszewskiego, była prekursorska na gruncie polskiego i polonistycznego językoznawstwa wobec propozycji socjolingwistycznych. Socjolingwistyka polska, rozwijająca się od lat 70. XX wieku, przejęła za Williamem Labovem teorię społecznego rozwarstwienia języka według takich cech jego użytkowników jak: 1) pochodzenie społeczne, 2) wykształcenie, 3) zawód, 4) wiek, 5) pochodzenie terytorialne, 6) płeć [zob. Grabias, 1994, s. 88; Lubaś, 1979, s. 29; Labov, 1966].

Socjolingwistyczna zmienna wieku determinuje tu stosowanie kategorii pokolenia przede wszystkim w ujęciu generacyjno-społecznym (biologicznym, rodzinnym) i rzeczywiście badania z tego zakresu na ogół przyjmują trójpokoleniową stratyfikację respondentów (informatorów) w zależności od ich zróżnicowania wiekowego. Można tu, odwołując się do przykładów najnowszych, wymienić np. monografię autorstwa Anny Zielińskiej czy też rozprawę doktorską Anny Suchodolskiej [zob. Zielińska, 2013, s. 387-407; Suchodolska, 2015].

W ten sposób kategoria pokolenia utrwaliła się we współczesnym językoznawstwie polskim, podejmującym problematykę społecznego kontekstu funkcjonowania języka. Dotyczy to również współczesnej dialektologii polskiej, która dziś bada przede wszystkim przemiany języka społeczności wiejskich w kontekście społecznych przekształceń współczesnej wsi, co - jak zawsze wymaga reprezentatywnego doboru respondentów:

Informatorzy powinni być kompetentni i merytorycznie, i językowo. Powinni zatem reprezentować różne warstwy zbiorowości wiejskich i różne pokolenia oraz mieć dobrą orientację w sprawach dotyczących rolnictwa i realiów językowych odnoszących się do tej sfery życia [Dubisz, Kosieradzki, 1991, s. VI-VII].

Dialektologia „,[...] w swoim zakresie odsłania tendencje innowacyjne, kierunki zmian, ukazuje ewolucję polszczyzny. [...] Poszerzyć je można o nowe tendencje i kierunki zmian w gwarach, które wynikają z większego niż w okresie międzywojennym czy w latach powojennych wpływu na gwary polszczyzny literackiej. [...] Najlepszą podstawąźródłową poznania gwarotwórczych innowacji są teksty" [Gala, 1998, s. 368, 369]. 
Jak już zaznaczono, przydatność kategorii pokolenia w analizach dialektologicznych bywa różna. Zależy to od celu badań, doboru informatorów, jakości zebranego materiału. Dla uchwycenia procesów dyferencjacji kodów komunikacyjnych zbiorowości wiejskich jest to jednak kategoria niezbędna.

Dla egzemplifikacji tej tezy podaję niżej trzy krótkie teksty, będące fragmentami wypowiedzi informatorek z jednej miejscowości, odpowiednio zróżnicowanych pokoleniowo.

Nagrań dokonano we wsi Słomianka - gmina Korycin, woj. białostockie w 1977 roku. Teksty te miały wejść do Nowego wyboru polskich tekstów gwarowych pod red. Mieczysława Szymczaka i Bogusława Dunaja, którego edycja nie doszła do skutku, ponieważ zgromadzone wówczas w Instytucie Języka Polskiego UW nagrania zostały w większości zarekwirowane i zniszczone przez służbę bezpieczeństwa po ogłoszeniu stanu wojennego w grudniu 1981 roku. Teksty podaję w transkrypcji uproszczonej. Znak / oznacza mocny akcent dynamiczny położony na danej sylabie.

Pokolenie najstarsze: Paulina Z., lat 79

Wesele

I weselje j/us. [...] Wes/ele - piek/ut' b/utki f pjecach. Pr/oste, na dr/ozdzach, nie stlotkie b/utki, zw/ykte b/utki, d/uzo [...] To z/eś b/edzie ft/orek, to blyto tak: ft/orki b/yli dziwow/iecer. Wj/anek wij/uć dla mołod/oj, śpiew/ajuć pjos/enki, af śrlodu ślup.

Pszyj/ezdza mt/odi, pojech/ali do śl/ubu, wz/ieli mołod/uchu i wj/ele b/yło flrow. Poj/echali do śllubu, prij/echali ot śllubu, no i m/atka z lojcem whietla ze s/olej jus s chlj/ebam, zep clurka iź/ęć d/olja byt/a. Bo s/ul'i chlj/ep clata z/ycie ctowj/eka. No i tancow/ali claty, fsz/ystko, fs/io, fs/io wes/ele tancow/ało.

I n/oc, a na dr/ugi dzi/eń chodz/ili od d/omu do d/omu, kto byt w ves/elju to prosili j/esce na śniad/anie. I muzyk/anty r/azem, i mołod/ucha, i mołod/yj, dr/udźbyj, i gr/ali w tlych ludilej, i zapras/ali na śniad/anie: kap/usta, kart/ofli byt/a, mj/ęso, i znaf popij/ali. I p/otem jus podjezdz/ali do mołod/oho. Tak, i byl/i u mołod/uchi vj/ela. Dzi/eń i n/oc as na dr/ugi dzi/eń, na vi/ecur poj/echali do mołod/oho.

Pokolenie średnie: Gabriela Z., lat 57

Życie na wsi

To dużo sie zmienito; teros jest ludzi inteligientniejsi na wsi, duzo rozwinienty, mtodzies jest ucona, chodzi do szkoty $i$ dalsze szkoty maja, i każdy dązy... te ży- 
cie polepszyć. Nasze życie było trudniejsze; pracowalje - mało mielje, a teros... mniej pracujem, a więc mamo.

No i co dalej [...]. No tak ..., ja mohe tys powiedzieć u nas tys byty dzieci dużo, prawda, i nikogo nie ma tera. Zostałam jedna z męzem; synek jeździ tylko do prac'i, a ile dzieci, chiba dziewięcioro f śfiecie jusz jest. I dobże majo, i majo taksy, a jagże, i televizory, i radja, i dużo rozumiejo, dużo vięcej jak ja. I liepij, $i$ dlia nich dużo liepij jest. Poruvnać ich życie a moje, to oo!

Dla mnie tys, a jagze: co ji po okupacji, tos my ni mieli nic, ani nic. Fszystko nam zabrano byto; tyl'ko jedyn dom i brudu petno było. A teros jednak i mi tysz jusz... dużo inacej rozumiemy ji liepiej. Cemu nie liepiej, pracujem ale coś mamo, pravda.

Pokolenie najmłodsze: Krystyna Z., lat 25

Nasza wieś

Nasza vieś jest bardzo duża, bardzo dużo jest muodzieży. Jest piẹkny klup. Vuaśnie f tym klubie sa zabavy, vieczorki rużne organizujemy. [...] Organizovaliśmy, poviedzieć, tak? ... i rużne jakieś potancufki, bo jes magnet i byua kierovniczka klubu. Vogle co sobote zabavy i co niedziele, bardzo uadne zabavy. [...] I bibloteka jes duża, i czytaliśmy ksiąszki rużne, pszetstavienia nawet były. Nieras do klubu zapraszaliśmy innom muodziesz ze fsi, żeby jakośs spendzić ten vieczur pszyjemnie.

No, ja się z mężem zapoznauam na zabawie. I oczyviście pracovauam razem $z$ nim. I autobusem tym samym dojeżḋauam do pracy. I tak się zapoznaunam.

No, na pevno życie na fsi jes teras dosyć lepsze, ulepszone i vięcej rozryfki muodziesz ma, jak kiedyś.

Łatwo można zauważyć, że nasycenie tekstów cechami odróżniającymi te wypowiedzi od potocznej polszczyzny jest różne w zależności od pokoleniowej przynależności respondentek. Bez wątpienia możemy stwierdzić, że respondentka należąca do najstarszego pokolenia mówi jeszcze gwarą ludową, respondentka reprezentująca pokolenie średnie posługuje się mieszanym (gwarowo-potocznym) wariantem języka, a respondentka najmłodsza wypowiada się już w potocznej polszczyźnie ogólnej z bardzo nielicznymi cechami regionalno-gwarowymi. Rejestry tych cech przedstawiają się w sposób zróżnicowany.

\section{Tekst 1., pokolenie najstarsze}

1) bardzo mocny (mocniejszy niż w polszczyźnie ogólnej) paroksytoniczny lub oksytoniczny dynamiczny akcent wyrazowy;

2) wschodniosłowiański pełnogłos, mający charakter zleksykalizowany; 
3) zanik rezonansu nosowego w wygłosie i w śródgłosie przed różnymi spółgłoskami: $e>e, u ; q>u$;

4) rozszerzenia artykulacji samogłosek w sąsiedztwie płynnych spółgłosek i w sylabach nieakcentowanych: $u>o ; e>a$;

5) mazurzenie;

6) wymowa l' miękkiego;

7) wymowa $t$ przedniojęzykowo-zębowego;

8) asynchroniczna wymowa spółgłosek wargowych miękkich;

9) wymowa $r z$ jako $r / / r$;

10) depalatalna wymowa $n$;

11) palatalna wymowa $t$;

12) artykulacja $g$ jako $h$;

13) skrócenia form wyrazowych;

14) gwarowe słownictwo.

\section{Tekst 2., pokolenie średnie}

1) samogłoski ścieśnione: $e>i$;

2) zmieszanie $i \chi y$;

3) rozszerzenie artykulacji samogłosek w sąsiedztwie płynnych spółgłosek: $i>e$;

4) mazurzenie;

5) wymowa l' miękkiego;

6) wymowa $t$ przedniojęzykowo-zębowego;

7) półmiękkie spółgłoski $c^{\prime}, d^{\prime}$;

8) artykulacja $g$ jako $h$;

9) gwarowe formy fleksyjne;

10) skrócenia form wyrazowych.

\section{Tekst 3., pokolenie najmłodsze}

1) konsonantyczna wymowa samogłoski nosowej $a$ w wygłosie;

2) depalatalna wymowa spółgłosek $n^{\prime}, l$ '.

Zróżnicowanie pokoleniowe w wyzbywaniu się gwary widać nie tylko po liczbie cech gwarowych, występujących w wypowiedziach reprezentantek trzech pokoleń, ale także w nasyceniu ich wypowiedzi tymi cechami (największe u respondentki najstarszej), odmiennej tematyce wypowiedzi oraz zwiększającym się wyraźnie zakresie słownictwa ogólnopolskiego. W wypadku tych tekstów kryterium pokoleniowe znajduje jednoznaczne potwierdzenie w warstwie języ- 
kowej wypowiedzi, poświadczając zachodzenie określonych procesów socjolingwistycznych w środowiskach wiejskich w drugiej połowie XX wieku.

\section{$* * *$}

Przedstawione wyżej przykłady zastosowania kategorii pokolenia w badaniach dialektologicznych nie wyczerpują - oczywiście - problematyki związanej z tą metodologia, mają jednak dla mnie wartość rozwiązań, których przydatność mogłem bezpośrednio stwierdzić w podejmowanych przez mnie badaniach.

\section{BIBLIOGRAFIA}

BAJERowa Irena, 2002, Dwie szkoły językoznawstwa polonistycznego XX w. konflikty i współpraca, „Analecta...”, XI, z. 1-2, s. 9-20.

BASARA Anna, 1965, Studia nad wokalizmem w gwarach Mazowsza (samogłoski ustne), Wrocław - Warszawa - Kraków.

BASARA Anna et al., 1959, Kwestionariusz fonetyczny do badań gwar polskich, Warszawa.

Boryś Wiesław, 2005, Słownik etymologiczny języka polskiego, Kraków.

Cygan Stanisław, 2011, Przejawy świadomości językowej mieszkańców wsi końca XX wieku na przykładzie Lasocina na Kielecczyźnie, Kielce.

Dejna Karol, 1973, Dialekty polskie, Wrocław.

Dejna Karol, 1976, Uwagi o programie i metodach ćwiczeń z dialektologii polskiej, „Poradnik Językowy”, 5, s. 289-292.

Doroszewski Witold, 1953, Przedmiot i metody dialektologii, „Poradnik Językowy", 1, s. 1-8; 2, s. 1-7; 3, s. 2-10, 4, s. 4-12.

Doroszewski Witold, 1962, Dialektologia a metoda historyczno-porównawcza, w: idem, Studia i szkice językoznawcze, Warszawa, s. 449-458.

Doroszewski Witold, red., 1964, Słownik języka polskiego, Warszawa, t. V.

Dubisz Stanisław, KosieradzKi Mariusz, 1991, Słownik gwary rolniczej, z. III:

Kwestionariusz do badań słownictwa gwary rolniczej, Warszawa.

Dubisz Stanisław, red. nauk., 2003, Uniwersalny słownik języka polskiego, Warszawa, t. VI.

Dubisz Stanisław, 2006, Problemy periodyzacji dziejów języka polskiego, w: Czynić słowami. Studia ofiarowane Krystynie Długosz-Kurczabowej, red. H. Karaś, Warszawa, s. 134-140.

DuBisz Stanisław, 2009, Dzieje języka polskiego jako problem badawczy w pracy historyka języka, „Poradnik Językowy”, 3, s. 19-34. 
DuBISz Stanisław, 2013, Dialekt i gwara - integracja językowa - stylizacja gwarowa, w: idem, Językoznawcze studia polonistyczne (pisma wybrane, uzupełnione, zmienione), t. I: Dialektologia i jej pogranicza, Warszawa, s. 37-66.

GaLA Sławomir, 1998, Dialektologia jako przedmiot dydaktyki polonistycznej, w: Teoretyczne, badawcze i dydaktyczne założenia dialektologii, red. idem, Łódź, s. 365-370.

Grabias Stanisław, 1994, Język w zachowaniach społecznych, Lublin.

KAMIŃSKA Aneta, 2007, Kategoria pokolenia we współczesnych badaniach nad społeczeństwem i kultura, „Kultura i Historia”, 11, http://www.kulturahistoria. umcs.lublin.pl/archives/113 (dostęp: 2.10.2015).

Karaś Halina, 2012, Perspektywy polskiej dialektologii, „Poradnik Językowy”, 8, s. 15-28.

KARAŚ Mieczysław, 1968, Diachronia i synchronia w ujmowaniu faktów dialektologicznych, „Zeszyty Naukowe UJ” - „Prace Językoznawcze”, 21, s. 7-15.

KuRKowsKa Halina, red., 1981, Współczesna polszczyzna. Wybór zagadnień, Warszawa.

Labov William, 1966, The Social Stratification of English in New York City, Washington.

LuBAŚ Władysław, 1976, Diachronia i synchronia w uniwersyteckim nauczaniu dialektologii, „Poradnik Językowy”, 5, s. 282-288.

LuBAŚ Władysław, 1979, Społeczne uwarunkowania współczesnej polszczyzny. Szkice socjolingwistyczne, Kraków.

Nitsch Kazimierz, 1955, Północno-polskie teksty gwarowe od Kaszub po Mazury, Kraków.

Nitsch Kazimierz, 1957, Dialekty języka polskiego, Wrocław.

Pelcowa Halina, 2012, Nowe wyzwania a tradycyjne metody badań dialektologicznych, „Poradnik Językowy”, 8, s. 5-14.

SęKOwSKa Elżbieta, 1995, Język zbiorowości polonijnych w krajach anglojęzycznych. Zagadnienia leksykalno-słowotwórcze, Warszawa.

SŁAWSKI Franciszek, 1958-1965, Słownik etymologiczny języka polskiego, Kraków, t. II.

Suchodolska Anna, 2015, Międzynarodowe słownictwo kardiologiczne i kardiochirurgiczne - na przykładzie języka polskiego, rosyjskiego i angielskiego (terminologia - profesjonalizmy - słownictwo środowiskowe), Warszawa.

TASZYCKI Witold, 1961, Co to jest dialektologia historyczna, w: idem, Rozprawy i studia polonistyczne, Wrocław, t. II, s. 275-287.

URBAŃCZYK Stanisław, red., 1972, Słownik staropolski, Wrocław - Warszawa - Kraków - Gdańsk, t. VI, z. 5. 
WyKa Kazimierz, 1977, Pokolenia literackie, Kraków.

ZieliŃsKa Anna, 2013, Mowa pogranicza. Studium o językach i tożsamościach w regionie lubuskim, Warszawa.

ZARĘBA Alfred, 1955, O metodach i technice badań gwarowych, „Biuletyn Polskiego Towarzystwa Językoznawczego", XIV, s. 140-155. 